\title{
Article \\ Understanding Mass Atrocity Prevention during Periods of Democratic Transition
}

\author{
Stephen McLoughlin \\ Centre for Governance and Public Policy, Griffith University, Brisbane, QLD 4222, Australia; \\ E-Mail: s.mcloughlin@griffith.edu.au
}

Submitted: 10 May 2015 | In Revised Form: 23 August 2015 | Accepted: 24 August 2015 |

Published: 27 October 2015

\begin{abstract}
The purpose of this article is to provide a better understanding of why some countries experience mass atrocities during periods of democratic transition, while others do not. Scholars have long regarded democracy as an important source of stability and protection from mass atrocities such as genocide, crimes against humanity and ethnic cleansing. But democratic transition itself is fraught with the heightened risk of violent conflict and even mass atrocities. Indeed, a number of studies have identified regimes in transition as containing the highest risk of political instability and mass atrocities. What is overlooked is the question of how and why some regimes undergo such transitions without experiencing mass atrocities, despite the presence of a number of salient risk factors, including state-based discrimination, inter-group tension and horizontal inequality. Utilizing a new analytical framework, this article investigates this lacuna by conducting a comparative analysis of two countries-one that experienced atrocities (Burundi) during transition, and one that did not (Guyana). How countries avoid such violence during transition has the potential to yield insights for the mitigation of risk associated with mass atrocity crimes.
\end{abstract}

\section{Keywords}

Burundi; democratic transition; Guyana; mass atrocities; prevention; risk

\section{Issue}

This article is part of the special issue "Mass Atrocity Prevention", edited by Professor Karen E. Smith (London School of Economics and Political Science, UK).

(C) 2015 by the author; licensee Cogitatio (Lisbon, Portugal). This article is licensed under a Creative Commons Attribution 4.0 International License (CC BY).

\section{Introduction}

In 1993, Burundi conducted free and fair elections after nearly thirty years under one party Tutsi-led authoritarian rule. The results heralded a new government under a diverse yet ostensibly Hutu-led party, Front pour la Démocratie au Burundi (Frodebu). Six months later, in an attempted military coup, soldiers abducted and assassinated its president, Melechior Ndadaye, along with Pontien Karibamwi and Gilles Bimazubute, the president and vice president of the National Assembly. This triggered a new wave of violence against both $\mathrm{Hu}-$ tus and Tutsis, and became the precursor to a drawnout civil war, resulting in further atrocities that resulted in the killing of up to 400,000 civilians. A year earlier in
Guyana, the country also conducted free and fair elections for the first time in nearly thirty years. There, the minority African Guyanese government lost power to the larger Indian Guyanese-dominated party. While the tensions between the two groups remained high, and some post-election violence occurred, regime change took place in a climate of relative calm. Why did Burundi's transition herald mass killing and civil war? And how did Guyana, a country with similar risk factors, ${ }^{1}$ manage to avoid such violence?

The purpose of this article is to outline an agenda for studying the relationship between democratic tran-

\footnotetext{
${ }^{1}$ By "risk factors" I refer to factors that are commonly understood to be long-term antecedents to mass atrocities.
} 
sition and mass atrocities. ${ }^{2}$ Scholars have long regarded democracy as an important source of stability and protection from mass atrocities (Harff, 1998, 2003; Krain, 2000 , pp. 45-46). But democratic transition itself is often fraught with heightened risk of violent conflict and even mass atrocities (Collier, 2009; Goldstone \& UIfelder, 2004; Mann, 2005; Snyder, 2000). ${ }^{3}$ Both Snyder (2000, p. 88) and Mann (2005, p. 4) point out that nascent democracies, or countries in the early stages of transition from authoritarian rule are particularly at risk of identity-based divisions become the main fault line of electoral competition.

To date, there is limited knowledge on why some democratic transitions give rise to mass atrocities and others do not. Indeed, research into the causes of mass atrocities have overwhelmingly focussed on cases where such violence has occurred, and very limited understanding and emphasis is placed on the conditions that inhibit the perpetration of mass atrocities, despite high-risk conditions (Human Security Report, 2011; McLoughlin \& Mayersen, 2013; Straus, 2012). Scholarship in the field of comparative genocide studies has generally overlooked the question of why genocide and other mass atrocities do not occur, despite the fact that the preconditions-or risk factors-commonly associated with such violence manifest far more frequently than such violent outcomes themselves (Straus, 2012, p. 343). Incorporating a better understanding of negative cases has the potential to yield fresh insights into prevention. In particular, it considers the question of what local and national actors are doing to mitigate the risk associated with mass atrocities, providing a counterbalance to much of the literature on conflict and mass atrocity prevention, which typically prioritizes external actors (McLoughlin, 2014a, pp. 418-419).

One approach to better understanding the nature of mass atrocity risk during periods of democratic tran-

\footnotetext{
2 I define mass atrocities as widespread and systematic violence targeted against unarmed civilians, such as genocide, crimes against humanity, ethnic cleansing and war crimes.

${ }^{3}$ For the purposes of this analysis, I use the terms "democratic transition" and "democratization" to refer specifically to the initial process of moving away from authoritarian forms of rule to a process whereby, to use Linz and Stepan's words, "sufficient agreement has been reached about political procedures to produce an elected government, when a government comes to power that is the direct result of a free and popular vote..." $(1996$, p. 3). While Linz and Stepan also stipulate that such a transition is complete when the ability to generate new policies is apparent, and the separation of power between executive, legislative and judicial power is apparent, I am particularly interested in the early stages of transition, when such processes are under construction. The reason for this is that scholars have identified the early stages of transition as being time when violence is most likely under certain circumstances. How and why some countries manage to navigate this phase while others do not is the question under investigation here.
}

sition is to conduct in-depth analyses of both positive and negative cases-countries that have embarked on a period of transition, distinguished by the perpetration or avoidance of mass atrocities (see, for example, Mayersen \& McLoughlin, 2011; Straus, 2012). ${ }^{4}$ My aim in this paper is threefold: to investigate the impact that long-term risk factors associated with mass atrocities have on countries undergoing democratic transition; to better understand how and why such risk becomes more acute during such periods; and finally, to identify and trace the political, economic and social processes that are instrumental in the avoidance of atrocities on the one hand, and in their perpetration on the other. In this article I present an analytical framework which forms the basis of such an investigation. Following this, I use the framework to conduct a brief analysis of one positive case (Burundi) and one negative case (Guyana). The purpose of the comparative analysis is to illustrate, in broad terms, how and why mass atrocity risk escalates and de-escalates during periods of democratic transition.

By conducting such an analysis I do not intend to argue that were it not for certain factors, outcomes in each country would have been dramatically different. Rather, the purpose here is to contribute to the growing body of research within comparative genocide studies, which seeks to redress the over-emphasis on "what goes wrong", by incorporating cases where similar patterns of risk have been effectively mitigated over time (see for example, Mayersen \& McLoughlin 2011, p. 248). By doing so, this analysis seeks to provide a more nuanced understanding of the causes of mass atrocities during periods of democratic transition, and to gain insights useful for prevention.

\section{Background and Analytical Framework}

Since the end of the Cold War, many states have sought to transition from authoritarian to democratic forms of governance. Many western states view this as a favourable development, and have invested considerable resources in support of democratization (DFAT, 2013; DFID, 2013; USAID, 2013). However, there has been a more mixed assessment to democratic transition within the literature on civil wars, genocide and other mass atrocities, due to evidence that transitions can increase the risk of mass atrocities (Collier, 2009; Collier \& Rohner, 2008; Mann, 2005; Snyder, 2000). There is no question that democratic regimes are far less likely to commit mass atrocities than autocracies, (see, for example, Harff, 2003, p. 66, and Rummel,

\footnotetext{
4 The most common approach to understanding the causes of mass atrocities is to compare past cases where such violence has occurred. This is the dominant methodological approach in the field of comparative genocide studies, as Straus (2012, p. 343).
} 
1994, pp. 23-24; 1997, p. 405). However, the process of transitioning authoritarian rule can be perilous. In successive large- $N$ studies conducted by the Political Instability Task Force (PITF), countries undergoing transition were found to be at greatest risk of political instability-genocide, rebellion, revolution or violent regime change-often characterized by mass atrocities. Another large- $N$ study found that when poor countries (a per-capita GDP of less than US\$2,750) undergo democratic transition, the risk of rebellion increases considerably (Collier \& Rohner, 2008, p. 534), and with it the chances of mass atrocities. In addition, two strong claims emerged from two small- $N$ studies: that "murderous ethnic cleansing" is "a hazard in the age of democracy", especially in new democracies (Mann, 2005, pp. 1-2); and that the international push for rapid democratization can lead to "nationalist conflict" if the process is commenced while national institutions are still weak, as it did in Rwanda and Burundi (Snyder, 2000, p. 16).

While this research clearly demonstrates the heightened risks associated with democratic transitions, there are a number of significant oversights. First, very little has been written about how regimes undergoing democratic transition avoid mass atrocities. Countries such as Ghana, Malawi, Zambia and Guyana all underwent democratic transitions without experiencing atrocities, despite the presence of risk. Second, although large- $N$ studies identified heightened risk, we still do not fully understand what factors reduce risk during transitions.

To better understand why these different outcomes unfolded during democratic transition in these two cases, I use a three-tiered analytical framework. The first tier identifies key structural risk factors associated with mass atrocities: politicized social division, stateled discrimination (including the political and social exclusion of people, on the basis of identity), low economic inter-dependency, horizontal inequalities and prior atrocities (Goldstone \& Ulfelder, 2004; Harff, 2003; McLoughlin, 2014).

Building on this, the second and third tiers are tailored specifically for periods of democratic transition. The second tier consists of key claims about the nature of risk during democratic transition, such as a dominant chief executive, factional division (political division on the basis of ethnic, racial or religious identity), and low GDP (Collier, 2009; Goldstone \& Ulfelder, 2004; Mann, 2005; Snyder, 2000).

The third tier identifies local and national sources of resilience, which have the capacity to mitigate risk. These include policies that promote social cohesion, inclusive leadership prior to transition, strong rule of law, diffusion of power, and policies promoting horizontal equality (Carnegie Commission on Preventing Deadly Conflict, 1997; Human Security Report, 2011; McLoughlin, 2014). The purpose of this part of the analytical framework is to identify and analyse processes of risk mitigation, or the breakdown of risk mitigation, during democratic transition.

\section{Case Study Selection and Analysis}

The choice of Burundi and Guyana rests on three premises. First, prior to transitions, each country contained structural risk factors associated with mass atrocities. The second is evidence of heightened risk during the transition away from authoritarian rule. For example, in both countries, electoral competition was fought along entrenched identity-based differences that had been a major source of tension (and indeed violence) in the past. The third premise is the point of difference between the two countries - that is, the occurrence (or not) of mass atrocities.

Both countries were subject to authoritarian rule by minority-led parties, whose authority was supported by minority-led militaries. Politicized identity-based tensions in both countries were characterized by two dominant identity groups-minority Tutsis and majority Hutus in Burundi; and in Guyana, between the minority African Guyanese, and the more numerically dominant Indian Guyanese. Minority-led rule fuelled these tensions through state-led discrimination in both countries.

There are also points of difference. While both countries experienced inter-ethnic conflict either in the early stages of independence, or in the final years of decolonization, the atrocities committed in Burundi, mostly against Hutus, far eclipsed the violence in Guyana. Moreover, the tensions in Burundi were further complicated by the violent dynamics unfolding in Rwanda, which had a strong impact on the country's political stability and inter-ethnic relations. Yet despite these differences, the comparative value of these two cases rests in the bipolar nature of identity-based tensions, and the fact that both countries endured almost three decades of authoritarian rule and entrenched discrimination, with minority-led regimes in control. While other countries going through transition at similar times-such as Zambia and Ghana-and indeed would certainly add value to a larger study, the particular configuration of risk in Burundi and Guyana, along with their broad commonalities, contribute to their comparative value.

There are two other benefits of this comparative analysis. First, it provides a platform for exploring why it is that on the one hand the prior atrocities in Burundi were surpassed by the length and severity of violence that ensued in 1993 and beyond; while on the other, it seeks to provide reasons as to why it was Guyana's democratic transition managed to navigate challenges in a way that resulted in the isolated cases of postelection violence falling far short of the limited atrocities committed in the lead-up to independence. Sec- 
ond, it provides a lens over the contrasting ways that each country managed a hostile security sector during the early stages of transition; as I explore further below, the behaviour of the armed forces and the police during transition was a crucial dimension to the escalation or de-escalation of risk in both countries. While the circumstances that unfolded in both countries were contextually specific, there are broad lessons for prevention that can be gained, which could provide insights for other countries facing similar risk factors.

\subsection{Burundi}

From the advent of independence in 1962 to the resumption of free and fair elections in 1993, Burundi contained three long-term risk factors associated with mass atrocities: politicized social division, state-led discrimination, and prior atrocities.

Politicized tensions between Tutsis and Hutus were already acute by the time the territory embarked on independence. While society in pre-colonial Burundi had been unequal, within a royal hierarchy that attributed more power overall to Tutsis (approximately 14 per cent of the population) over the majority Hutus (85 per cent of the population), the Kingdom's princely class, the Ganwa were neither Hutu nor Tutsi, and many Hutus exercised positions of power. Belgian colonial influence made the relations more rigid-while ruling indirectly, they placed all political and economic power in the hands of the Ganwa and Tutsi, further depriving the majority Hutu (Lemarchand, 1996, pp. 41-57).

This strict division of power underscored tensions in the initial phase of independence, when Burundi's constitutional monarchy presided over a parliament with both Hutu and Tutsi representatives, in the ruling party, Union pour le Progrès National (Uprona). Despite the initial promise of an ethnically diverse political landscape, the competition for power over key positions spilled into violence. Burundi's first prime minister, Pierre Ngendandumwe (a Hutu), was assassinated by a Rwandan Tutsi refugee in 1965 . The king appointed a Ganwa as a successor, a move that angered the majority Hutu parliament. An attempted coup by the Hutu army officers in year was crushed by the Tutsidominated army. Soon, however, competition for control of the state was played out between Hutu and Tutsi elements within the government. A Tutsi-led military coup consolidated this power in the hands of Tutsi elites, while at the same time eliminating all Hutu leaders from key positions within the bureaucracy and military (Wolpe, 2011, p. 8). Firmly in control of the security forces, the army launched a coup in 1966, declaring the advent of the First Republic. ${ }^{5}$ In the wake of the

${ }^{5}$ The Second (1976-1987, under Lt. Col. Jean-Baptiste Bagaza) and Third (1987-1993, under Maj. Pierre Buyoya) Republics coup, the army installed a predominantly Tutsi government, turning Uprona into an instrument for Tutsi control (Lemarchand, 1996, p. 74). While in neighbouring Rwanda Hutus overthrew the monarchy and removed Tutsis from power, in Burundi Tutsi elites maintained their hold on power through repressive military rule that lasted for three decades. This hold on power compounded the grievances felt by Hutus.

From the beginning of the First Republic, state-led discrimination against Hutus escalated and became increasingly entrenched. With the Tutsi elites' gaining control of the mechanisms of state, a range of repressive measures were enacted. Hutus were deprived of parliamentary representation. By the 1980s, seventeen Hutu MPs made up the sixty-five-seat parliament. The exclusion became even more acute in the cabinet, where only four of the twenty ministries were given to Hutus. In Uprona's fifty-two-member Central Committee, only two Hutus were present. There was one Hutu ambassador of the twenty-two posts available; and only two out of fifteen governors were Hutu (Uvin, 2009, p. 10). Yet even among Tutsis, representation was disproportionate. Most of the upper echelons of the military, as well as Burundi's three presidents between 1965 and 1993 were Tutsi-Hima ${ }^{6}$ from Bururi province in the southwest of the country (Uvin, 2009, p. 9). This added greater complexity to the discrimination in the country-not only were ethnic Hutus profoundly under-represented in government, but control was firmly the hands of Tutsi elites from one province.

Exclusion was evident in educational opportunities, although both Hutus and Tutsis suffered. Hutus were under-represented at tertiary level, while amongst Tutsis, Bururi province was again disproportionately favoured. Indeed, 60 per cent of international aid for education was reserved for Bururi-Bururi students comprised 15 per cent of the total enrolments at the University of Burundi (Uvin, 2000, p. 10). The most deprived were Hutus. Of the small pool of students who went onto secondary school following primary education, considerably less than half were Hutus. At university level, only a third of enrolments were Hutu (Lemarchand, 1996, pp. 108-109). Indeed, allocation of teachers and resources for education at all level varied greatly throughout the country. Bururi received the greatest resources. Other provinces, including Bujumbura City, Makamba, Gitega, Muramvya and Mwaro also received a generous share of resources. Other provinces in the north and the east of the country, received less than half of all teachers and resources, despite comprising more than two thirds of the population (Jackson, 2000, p. 25). Most Hutus were deprived of

were also the result of coups.

6 Tutsi-Hima are Tutsis who are largely (but not entirely) from Bururi province, known for their anti-monarchical stance (Lemarchand, 1994, pp. 11, 81). 
education and opportunities for employment within the state sector (including the army and the police); and these limitations resulted in an inequality of economic opportunity. This uneven distribution of resources had two effects. First, it favoured Tutsis in some provinces, and second, it heightened ethnic rivalry in the north and the east (Lemarchand, 1996, pp. 122-123).

The over-representation of Tutsis at tertiary level had a flow-on effect with public sector recruitment, with most bureaucratic positions going to Tutsi graduates (Lemarchand, 1996, p. 65). The public sector was the primary source of wealth and opportunity in Burundi, so the inequality of opportunity that existed at all levels of the education system. This further compounded the exclusion of Hutus, while at the same time fostering a Tutsi elite who had control of import licences and other profit-making opportunities. This discrimination in the education and the public sector had a profound impact on inter-ethnic tensions, in the early 1970s, when it became increasingly clear that many Hutus had no purchase in Burundi's First Republic. As Lemarchand notes, "state-society interactions took the predictable form of increasingly brutal encounters between a Tutsi-dominated army and the Hutu opposition" (1996, p. 80).

Indeed, previous responses by the Uprona regime to Hutu opposition dramatically compounded the risk of atrocities during the transition in 1993. As Harff points out, one of the most the significant impacts on the risk of future atrocities, is prior atrocities (2003, p. 66). There were two instances in Burundi's recent history where atrocities were perpetrated against Hutus. The first was the military regime's resorting to the most brutal tactics to crush dissent in 1972. In April of that year, a loose coalition of Hutus - students, schoolteachers, petty traders, some refuges from Zaire and some elites in Bujumbura-carried out a massacre of Tutsis, numbering in the thousands (Lemarchand, 1996, pp. 93-96; Mthembu-Salter, Berger, \& Kikoler, 2011, p. 3). The response from Burundi's army was brutal and swift. First, they engaged in counterinsurgency strategies against the rebellion. Then they targeted all Hutus they suspected as having been part of the rebellion. In the process they conducted a pogrom that killed up to 250,000 Hutus, and displaced many more (Abrams, 1995, pp. 147-148; Bowen, Freeman, \& Miller, 1973, p. 1; Chrétien, 2003, p. 316; Uvin, 2009, p. 10; Weinstein, 1972, p. 17). ${ }^{7}$ Almost all educated Hutus were killed, further depriving them of access to the mechanisms of power.

\footnotetext{
7 The precise numbers killed vary according to different sources. Uvin, for example, estimates over 80,000 were killed, while Chrétien claims that at least 150,000 were killed. Both Weistein and Bowen et al. estimate the deaths to be up to 250,000 .
}

Tensions peaked again in 1988 under new president Pierre Buyoya. Buyoya promised to bring about a rapprochement between Hutus and Tutsis by lifting restrictions on freedom of expression and releasing Hutu political prisoners (Lemarchand, 1996, p. 119). This lifted hopes, but also triggered student strikes, mainly in secondary schools. This led to another increase in tensions, particularly in the western provinces of Ngozi and Ntega, which shared borders with Rwanda, and housed large numbers of Rwandan Tutsi refugees. In Ngozi province in particular, the Tutsi administrator of the Marangara commune invoked violent rhetoric in his efforts to quash what he perceived as "illegal and nocturnal tribalist reunions" among the Hutu community. This rhetoric brought back memories of 1972, further compounding tensions. Violence broke out in neighbouring Ntega, provoking inter-ethnic attacks on both sides. The army intervened, crushing the violence while specifically targeting the Hutu population, including women and children (Lemarchand, 1996, pp. 120127). Casualties numbered around 20,000 , according to Human Rights Watch (2009).

These atrocities compounded risk in two main ways. First, they caused mass displacement, in particular resulting in growing refugee numbers in Tanzania. It was amongst the refugee community that Hutu militias gained strength. Chief among these were the Parti pour la Libération du Peuple Hutu (Palipehutu), which had emerged in the diaspora community in Tanzania after the 1972 mass killings. Hutu groups that initially provoked unrest in 1988 were organized by Palipehutu. Palipehutu were committed to overthrowing the Uprona government, and seeking retribution for the 1972 killings (Uvin, 2009, pp. 11-12). Consequently, they were not interested in power sharing options that could arise from a process of democratization, thus viewing democratization as a threat to their own power. Second, these two atrocities were instrumental in further entrenching cleavages between Hutus and Tutsis, already salient as a result of decades of discrimination and disenfranchisement. With a Tutsi-led military at one end of the spectrum, and Hutu militia groups at the other end, the space for moderate Hutu and Tutsi elites appeared fraught from the outset. While the 1988 atrocities spurred Buyoya to reform Burundi's political landscape, and ultimately embark on democratization, as Lemarchand points out, it also resulted in a "further hardening of ethnic lines" (1994, p. 590). As Burundi was about to embark on its democratic transition, ethnic tensions were becoming more pronounced.

Thus, up until the early 1990s, Burundi's history was one of political repression, in which the Tutsidominated military regime discriminated against Hutus, and treated dissent with extreme violence. In other words, Burundi's first three decades of independence were marked by repressive rule, widespread 
discrimination, and atrocities. Hutu refugee camps in Tanzania had spawned militia groups such as the Palipehutu, while Tutsi refugees from Rwanda had spurred Tutsi elites in Burundi to take a hard line against Hutus.

Burundi's democratic conducting of free and fair elections in 1993 followed a five-year period of liberalization. While there was international pressure for Burundi to democratize, particularly coming from international donors (Snyder, 2000, p. 300), to initiate democratic reform the political will on the part of Buyoya and others in the government, was also strong. Following the 1988 atrocities, Buyoya enacted a number of new policies designed to give greater freedom to all of Burundi's citizens. He included more Hutus in the government, appointing a Hutu prime minister; he introduced a Charter of National Unity, which sought to lift discrimination experienced by Hutus. Most importantly, he introduced a new constitution, which included provisions that placed clear limits on executive power, established the importance of human rights, and sanctioned a multi-party democracy (Lemarchand, 1996, p. 131). The constitution was put to a referendum in 1992 with an overwhelming majority voting in its favour (African Elections Database, 2015). Thus, it was during Buyoya's tenure that the exclusion of Hutus in government and the public sector began to receive redress. Indeed, with the raft of liberalization measures that took place between 1988 and 1993, the country's return to free and fair elections was the culmination of five years of preparation.

However, this push for reform did not put an end to tensions that had remained high after the 1988 atrocities. Instead, between 1988 and 1993, inter-ethnic tensions escalated. Burundi's economic decline contributed to these tensions. From the late 1980s the country endured negative growth and increasing debt, which in no small part was due to a drop in the price of coffee; and imposed structural adjustment policies exacerbated inequalities (Uvin, 2009, p. 11). Pressure from refugee communities also mounted. Burundi's neighbouring countries had been accommodating mostly Hutu refugees since the atrocities in 1972. In 1991 the estimated refugee population was 240,000 , mostly living in Tanzania. With limited resources available, it proved to be prohibitively costly-only a few thousand were repatriated prior to 1993 (Lemarchand, 1996, pp. 172173). Complicating things further, some members of the repatriated populations engaged in antigovernment violence in late 1991, further deepening the tension that had already existed (Lemarchand, 1996, p. 173).

In addition to this, the 1993 campaign further aggravated tensions between Hutus and Tutsis. During the campaign, electoral competition was characterized by two major parties - the Hutu-supported Front pour la Démocratie au Burundi (Frodebu), and the incumbent Tutsi-led Uprona. Many Tutsis who attempted to join Frodebu were often branded as traitors, and were the target of physical intimidation by Uprona supporters (Reyntjens, 2005, p. 10). Palipehutu's members also sought to further aggravate tensions-the militia increased its infiltrations from Tanzania, while rumours of the army's plans to retaliate with brutal force began to abound (Uvin, 2009, p. 12). Palipehutu's professed goal of Hutu domination, along with its attempts to undermine democratic reform resulted in it not receiving legal recognition as a political party in the lead-up to the elections, which prompted them to further escalate tensions through demonstrations and terrorist attacks (Prunier, 1994, p. 16). In response, many Palipehutu members joined Frodebu, a move which spurred Uprona to accuse the party of being the "legal arm" of Palipehutu. The presence of Palipehutu within Frodebu further cemented this ethnic polarisation in the lead-up to the 1993 election; and indeed, after the election, many local Frodebu leaders throughout the country were also Palipehutu militants (Reyntjens, 2005, p. 10).

At the same time, the one sector that Buyoya was not able to influence in terms of personnel, was the army, meaning that the security sector, which had wielded considerable power, remained under the control of Bururi Tutsis. The military defied changes that Buyoya had initiated to facilitate democratizationthere were unsuccessful coup attempts in 1989 and 1992, reflecting the increasingly obstructive role that the security sector were playing (Reyntjens, 1993, p. 565). While the military's chief of staff publicly endorsed the newly elected president Ndadaye, following the 1993 election, mistrust between the army and the new government remained high (Reyntjens, 1993, p. 578). Burundi's internal security was becoming harder to manage.

The election in July yielded a predictable outcome. Frodebu received nearly two thirds of the vote, effectively ending thirty years of Tutsi rule. In a spirit of rapprochement, following the precedent set by Buyoya after 1988, the new president, Ndadaye included a number of Tutsi representatives in the new cabinet, not dissimilar from that of Buyoya from the late 1980s. With the peaceful change of power, Burundi's transition initially inspired great optimism. However, it was at the lower levels of governance that rapid change of personnel took place-provincial governors and communal leaders were almost entirely replaced by Frodebu cadres (Uvin, 2009, p. 13). For the military, the concern of the rapid Frodebu'ization of the government (and fears the military would be next) spurred an attempted coup in October 1993.

The coup that was instigated by the eleventh battalion of the army (and joined by other elements) was ultimately unsuccessful in establishing a new government, but violence soon followed in the ensuing chaos. The battalion apprehended Ndadaye, as well as the 
president and vice-president of the national assembly, assassinating them soon after. Other members of the government sought refuge with the French embassy, demanding international protection in the wake of the attempted coup. With the government in hiding, and the army rejecting any request for foreign involvement, the ensuing violence unfolded in a power vacuum (Reytnjens, 2005, p. 14). The assassination of Ndadaye provoked an immediate reaction throughout Burundi. Many Frodebu officials-ostensibly Palipehutu members-organized retaliatory violence against Tutsis, and prepared to mount a resistance against the army by blocking roads and destroying bridges. As in 1972 and 1988, the army also responded, engaging in widespread killing, committing "widespread and indiscriminate repression of ordinary Hutu peasants" (Prunier, 1994, p. 24; Reyntjens, 2005, p. 14; Uvin, 1999, p. 262). Violence committed on both sides resulted in the killing more than 50,000, and displacing up to one million people (Reyntjens, 2005, p. 14; Uvin, 1999, p. 262). Extremist actors on both sides stepped up attack and counter-attack.

While some order was regained in 1994 with a compromise government (consisting of Uprona and Frodebu elements), this soon fell apart after the new president (Ntyamira) was killed in the plane crashed that also killed the Rwandan president Habyarimana, triggering the genocide there. Although Uprona and Frodebu managed to agree on an equal number of ministries by the end of 1994, the new government was marred by growing factional division between the two parties, rendering the government unable to function. Eventually another coup was instigated in 1996, this time initiated by Buyoya. Once again, a similar pattern of violence followed-Hutu militias attacked Tutsi militia groups and army barracks, pre-empting what was perceived to be an inevitable return to anti-Hutu violence. Tutsi militia groups, and the army then terrorized the Hutu population, engaging in disproportionate reprisal attacks (Uvin, 1999, pp. 262-263; Uvin, 2009, pp. 14-15). Tensions were further escalated by unchecked hate propaganda-printed publications often incited anti-Hutu violence, and even printed the names of Hutu government workers to be targeted (Uvin, 1999, p. 262). By 1998 the violence claimed the lives of more than 200,000, and by the 2006 truce up to 400,000 lives were lost, with 800,000 having fled the country (Wolpe, 2011, p. 5).

In accounting for why civil war and widespread atrocities were committed during the transition, risk factors associated with transitions need consideration. The first is executive power. Given the peaceful change of office that occurred after the election, executive power appeared to be functioning as it was meant to in the new democracy. However, factional division was still a salient issue, despite the efforts of both Buyoya's government and the nascent Ndadaye regime, two fac- tors need further exploration -the continuing factional divisions that characterized the violence; and the weakening of moderate Hutu and Tusti elites as tensions escalated.

Yet this factional division itself was complex. Within the government, there appeared to be greater interidentity cooperation than ever before. Both the previous and new governments demonstrated an explicit intention to ensure that both Tutsi and Hutu representatives were included. Buyoya's Third Republic government comprised equal numbers of Hutus and Tutsis, as did Ndadaye's 1993 government. On the surface, the growing inclusivity of the government seemed to address previous grievances based on Hutu exclusion. However, given the extent to which Hutus had been deprived of public sector positions since the 1960s, it was the new government's attempt to rebalance personnel in these areas (and the public pressure to do so), which led to elements within the military elites once again marginalizing moderates on both sides, and initiating another coup. The military was the only sector that Buyoya was not able to touch, during his efforts to rebalance political representation and recruitment within the government. The military itself was not simply disproportionately controlled by Tutsis-its leadership was controlled by Tutsis from Bururi. Thus, the threat that the democratic transition posed for military elites was not simply a manifestation of Hutu-Tutsi tensions, rather it was the threat to the hold of power enjoyed by Bururi Tutsis in particular.

The atrocities committed in late 1993 and early 1994 were the product of a complex array of structural risk factors, escalating tensions, and triggered by the attempted coup in which Ndadaye and other newly elected elites were assassinated. The long-term discrimination and repression of Hutus by the Uprona regime in Burundi was the primary driving factor behind the articulation of political competition along ethnic lines during the beginning of transition away from authoritarian rule. Prior atrocities in 1972 and 1988 compounded these grievances, and created a large diaspora population in neighbouring countries, from which extremist Hutu militias emerged. Principal among them was Palipehutu. It was no surprise that the major contender, alongside the incumbent Uprona was a predominately Hutu party, Frodebu. During the campaign, tensions between supporters of both parties were further aggravated by two things - the physical intimidation of Tutsis who actively supported Frodebu, and the infiltration of Palipehutu members within the ranks of Frodebu. Although the initial election went relatively smoothly, the entrenched Tutsi elite became threatened by replacement of personnel with Hutus. Although cabinet initially included many Tutsis, at lower levels within government departments, there almost all positions changed hands to Frodebu supporters. Many newly appointed officials in the provinces were 
members of Palipehutu, whose professed aim was retribution for past atrocities. Burundi's military was both indisciplined and increasingly concerned about the Frodebu'ization of the public sector. An attempted coup by one battalion, and the ensuing assassination of Ndadaye triggered an immediate reaction in provinces throughout the country, much of which was organized by local officials who had ties with Palipehutu. This saw Hutus attacking Tutsis. The military then responded, with widespread killing of Hutus.

\subsection{Guyana}

Guyana embarked on a transition away from authoritarian rule in 1992, with the holding of the country's first free and fair elections since 1964. Prior to this, the country contained three long-term risk factors associated with mass atrocities. The first is politicized tension between the country's two largest identity groupsAfrican Guyanese and Indian Guyanese. Second, during the period of one party dominance between 1964 and 1992, Indian Guyanese endured state-led discrimination, including disenfranchisement, unequal access to public sector positions, particularly in the country's police and military. Political opponents were also disproportionately targeted by the African Guyanesedominated police. Third, while the country did not endure violence on the scale that Burundi did, Indian Guyanese citizens were subject to widespread violence in 1963 and 1964 after uprisings throughout the country triggered a repressive response from the military, resulting in what Perry Mars has labelled "neargenocidal warfare" (2001, p. 260). Although this violence (less than 1000 civilian deaths) was on a much smaller scale than what had occurred in Burundi-both in 1972 and 1988-this episode nonetheless underscored tensions between both groups over the ensuing decades. Not surprisingly, these tensions found expression in political competition during the resumption of multi-party elections in 1992, with the defeat of the incumbent African Guyanese People's National Congress (PNC) to the Asian Guyanese dominated People's Progressive Party/Civic (PPP/C).

Guyana's first three decades of independence were characterized by tensions between the country's two major identity groups-African Guyanese and Asian Guyanese. Guyana's African population were transported to South America as slaves during Dutch colonial control in the $17^{\text {th }}$ and $18^{\text {th }}$ centuries. Under British control slavery was declared illegal in 1836. The colonial administration in Guyana imported indentured labourers from the Indian subcontinent to replace former slaves in the sugar cane plantations (Hinds, 2010, p. 1). This new wave of Asian migration was a cynical move to subvert the prohibition of slavery-the new migrants earned marginally more than the African slaves had before. The administrators forbade the new- ly liberated African slaves from owning property or engaging in commerce, thus further entrenching their poverty. What unfolded was a duel tiered hierarchy of exploitation, with the newer migrants only slightly better off than the former group. This inevitably triggered tensions, and prompted both groups to organize politically to empower their own (see Wilson, 2012, pp. 77-78).

Tension between African and Indian Guyanese communities was further fuelled by the British colonial rule in the post-war period. Whenever one community staged an uprising, the British administrators tended to recruit members of the other community to suppress them (Mars, 2009, p. 508). When the British introduced universal suffrage in 1953, it retained control of the security forces. With the election of Cheddi Jagan and his socialist (and initially multi-racial but Indian-dominated) PPP, the colonial overseers suspended the constitution and maintained order through the African-dominated police force, under the command of British officers (Jagan, 1997, pp. 124-131; Mars, 2009, p. 510). With the PPP splitting after the 1957 election, African Guyanese leader Forbes Burnham formed the PNC, with political competition emerging along distinct ethnic lines. Election-related tensions increased, and the Africandominated security sector became increasingly at odds with the Indian Guyanese dominated government. Prior to independence, the British changed the electoral system from "first past the post" to proportional voting. This gave the "capitalist" PNC the edge in the 1964 election; successive elections beyond independence in 1966 maintained this status quo (until 1992) through a series of rigged elections. Under Burnham, the Africandominated armed forces enjoyed a close relationship, to the extent that they pledged allegiance to Burnham and the PNC, rather than the country. The combination of a minority-led government and a security sector doing the bidding of that government has strong parallels with the authoritarian system in Burundi.

Indeed, the political dominance of the PNC between 1964 and 1992 was supported by the African Guyanese-dominated military and police. The role the security sector played in support of the PNC government was particularly apparent in the aftermath of elections, which were typically flawed. Disputed election results often triggered post-election protests by Indian Guyanese PPP supporters, and these were frequently met with brutal repression by the police force. Opposition and authority in Guyana had a clear ethnic dimension-political protests were largely Indian Guyanese in character, and were usually repressed (often violently) by African security forces. In order to maintain its hold on power, the PNC invested heavily in the security sector, making Guyana the most militarized state in the Caribbean. As Hinds states, the implication was that the coercive apparatus of the state, under the control of the African Guyanese, functioned as a tool of African ethnic domination (2010, p. 41). 
Political power since independence in 1966 has been characterized by competition and tension between African Guyanese-roughly 30 per cent of the population-and Indian Guyanese-comprising approximately 43.5 per cent (Wilson, 2012, p. 88). Between $1964^{8}$ and 1992, Guyana was ruled ostensibly by an authoritarian regime controlled by the predominantly African Guyanese People's National Congress (PNC). As in Burundi, PNC supporters controlled government institutions during this period (Wilson, 2012, pp. 82-85). This control of government by a minorityled party fuelled tensions between government supporters and Indian Guyanese, who were mostly PPP supporters. The PPP was initially a socialist party that attracted support from both main groups, but dissatisfaction by some African Guyanese members at what they perceived as an imbalance in the leadership, spurred the formation of the PNC. Electoral competition became a zero-sum game, with the PPP and the PNC promoting policies that benefitted their ethnic supporter bases. Following a PPP victory in the 1961 elections, victory marches turned violent as their supporters levelled racial insults at Africans in the street. This then led to violent attacks against Africans in Indian-dominated villages; and the following year, many Indian Guyanese came under attack in Georgetown as tensions rose (Hinds, 2010, pp. 9-10). Violence escalated after the colonial administrators changed the electoral system to proportional representation, a move which saw the fortunes of the more favoured PNC rise against the socialist PPP. This underscored the identitybased violence, which grew as the territory moved towards independence.

The violence that erupted at this time was not on a scale that comes close to the atrocities committed in Burundi. Despite this, a violent episode in the 1960s compounded inter-ethnic tensions and made rapprochement and cooperation more difficult in the ensuing decades. In 1963 and 1964, the ethnic violence that erupted resulted in hundreds of deaths and widespread damage to property (Mars, 2001, p. 360). Following PNC control of the government from 1966, a litany of repressive attacks were committed against Indian Guyanese at strikes and political protests. Brutal tactics instigated by the African-dominated police against largely Asian protesters was the pattern of violence to follow, particularly during the years of PNC government control. One impact of this inter-ethnic conflict, particularly the violence that occurred on the eve of independence, was to drive a physical wedge between these two communities. Multi-ethnic villages

\footnotetext{
8 This was two years before independence, but this election heralded the government which would steward the territory to self-rule. Prior to this, in 1953, the British administrators introduced democratic representation through a colonial legislative council. The two major parties were formed in this period.
}

were commonplace, but after 1964 these diverse communities no longer existed due to the migration of ethnic communities. This saw the homogenization of regions and communities (Mars, 2001, p. 361). Not only did tensions remain high, but social cohesion suffered.

During the period of one-party rule by the PNC, from 1964 to 1992, Indian Guyanese citizens were subjected to exclusion and discrimination. In successive elections between 1966 and 1992, the PNC held onto power by conducting fraudulent elections (Hinds, 2010, pp. 11-17). This helped the PNC remain in power for more than two decades, despite the PPP having the backing of the more numerically dominant Indian population. One of the consequences of this was the favouring of Africans in the bureaucracy and security forces. Although the PNC ensured that the cabinet remained diverse, with representations from the Indian Guyanese community, the criteria for employment in the state sector became ethnicity as well as party affiliation. This was especially apparent within both the army and the military, where there were few Indian Guyanese represented (Hinds, 2010, p. 49; Wilson, 2012, p. 95).

Given these risk factors, it is not surprising that the introduction of free and fair elections in 1992 heralded political competition characterized by ethnic difference. Guyana's shift away from authoritarian rule was accompanied by ethnic-based factional division, which was reflected by the ethnic character of the two major parties. Because the Indian Guyanese population was larger in number than the African Guyanese, free and fair elections would inevitably herald a change of government. Yet the ranks of the police force and the military continued to be dominated by African Guyanese. Although the PPP attempted to broaden its appeal beyond its ethnic base by rebranding itself as PPP/Civic (PPP/C), the two major parties were still distinctly divided along ethnic lines. This time, the PPP/C's larger support base saw it victorious at the elections, heralding the presidency of Cheddi Jagan. Tensions between the two parties have also continued to simmer ever since, with the PNC supporters refusing to recognize the election results, and taking to the streets to protest. Between 1992 and 2001 in particular, election cycles were accompanied by low-level street violence (Hinds, 2010, pp. 23-25).

While Burundi's transition was stalled from the beginning through a violent backlash instigated by the Tutsi-led military, Guyana's relatively peaceful transition was by no means assured. In both countries rapid and widespread changes to personnel within the public sector took place. During the period of authoritarian rule between 1966 and 1992, public offices, police and military were dominated by African Guyanese, but declared their allegiance to the PNC first and foremost. So, in 1992, Guyana's democratic transition saw an African Guyanese dominated government (that had filled virtually all positions of public power with people of Af- 
rican background) on the verge of losing far more than an election. To compound these tensions, the after the victorious PPP gained power in the 1992 election, they "initiated a program of witch-hunting against top civil servants suspected of PNC sympathies" (Hinds, 2010, p. 21), much in the same way that Frodebu did.

Yet inter-ethnic tensions in Guyana simmered without dangerously escalating. Here, two sources of resilience had a positive impact. The first is the cooperation of the armed forces with the new government. Between 1985 and 1992, the security forces within Guyana-most importantly, the military and the policeevolved from being a supporter of the PNC, to participating in the transition process, and supporting the newly elected government. Although African Guyanese comprised 90 per cent of the armed forces, the military cooperated with the PPP/C government, allaying fears that they would instigate a coup. As Hinds states, "the upper echelons of the forces remain loyal to the government of the day" (2010, p. 41).

How did the armed forces-previously a tool for the PNC government-defer to the PPP/C government despite the new government's promise to reform the police and the army? One answer to this can be found in the action of the successor to Forbes Burnham, who died in office in 1985. His successor, Desmond Hoyte, came to power at a time when international pressure for Guyana to democratize was growing (Griffith, 1997a, p. 158; Wilson, 2012, p. 84). Hoyte was initially a supporter of Burnham's vision, but after becoming president, he determined that Burnham's leadership had been profoundly flawed, and that many of his "prescriptions and initiatives" had failed (Griffith, 1991, p. 150; Griffith, 1997b, p. 270). This, coupled with international pressure, prompted Hoyte to initiate a raft of reforms to facilitate democratization, improve human rights, and improve Guyana's stagnant economy (Griffith, 1997b, p. 270). The first step was to change the relationship between the PNC and the government. Prior to Hoyte's tenure, all branches of government had played a subordinate role to the PNC. Hoyte ended government funding of the PNC, and in doing so weakened the party's hold on the government (Griffith, 1997b, p. 270). He then reshuffled ministerial portfolios, demoted ministers who had been closely aligned with Burnham, (Griffith, 1997b, p. 270). This paved the way for the resumption of free and fair elections in 1992.

Given the close alignment between his predecessor and the armed forces, the question of how the armed forces would accommodate democratic change was a prescient one. Indeed there were lingering concernsboth domestically and internationally-that the military still retained their loyalty to the PNC, and might declare martial law during the 1992 campaign, in order to facilitate a PNC victory (Griffith, 1997b, p. 275). Hoyte took advantage of the retirement of MajorGeneral Norman McLean, controversially placing an In- dian Guyanese officer-Joseph Singh-as acting Chief of Staff of the Guyana Defence Forces. Singh became the first Indian Guyanese to be head of the defence forces (Griffith, 1991, p. 152). In addition, he repealed the National Security Act. The Act, introduced in 1966 allowed for detention without charge for up to three months of anyone who was deemed to be acting in a way "prejudicial to public safety or public order." Although it had never been used, its presence had been a source of fear, particularly among opposition supporters (Griffith, 1991, p. 154).

Hoyte appointed another man of Indian descentBalrum Raghubir-as Police Commissioner (Griffith, 1991, p. 152; Guyana Times, 2014). In 1989, Hoyte also introduced the Police Complaints Authority Act, in order to address nearly three decades of unchecked police brutality, levelled primarily at the Indian Guyanese population. Complaints were made public, and dozens were investigated each year. In 1989, for example, five police officers were charged with manslaughter after a death-in-custody case (Griffith, 1991, p. 154). Hoyte not only changed the leadership of the police, but also increased its transparency and accountability.

Hoyte's proactive move to bring about these changes precluded any potential internal resistance that might have arisen from a succeeding Indian Guyanese head of state attempting the same changes. While the armed forces was predominantly populated by people of African descent, the multi-ethnic character of the highest ranks was instrumental in ensuring that it was loyal to the democratically elected government, rather than the PNC specifically. This change of culture at the highest level had a strong effect on the political stability of the country during its democratic transition. According to Griffith, Hoyte's decision to change leadership in the police and the army prior to democratic elections in 1992, was crucial to the security forces going beyond their previously narrow allegiance to the PNC government (Griffith, 1997b, p. 275). In addition, Guyana did not have a history of military coups, unlike Burundi. In Burundi, the military had on numerous occasions initiate military coups to change leaders. By contrast, the security sector in Guyana had previously supported the PNC government, but had never enacted regime change through a coup. As such, the military in Guyana did not have the same ubiquitous hold over power that the military did in Burundi. Nevertheless, it was Hoyte's foresight that concluded that the strong relationship between his PNC government and the military needed to be addressed prior to the introduction of democratic elections, and he did this in the only way practically possible-by changing the leadership. It was impossible to alter the entire composition of the army and the police in a few short years, but greater diversity at the elite level saw a change in culture that precipitated a support of the elected government, which would inevitably be PPP- 
led. Having heads of police and army that understood and supported this transition was crucial to Guyana's transition (Griffith, 1997b, p. 275).

However, the security forces' elite-level support for the new government did not precipitate a major change in culture through the rank and file. The majority of soldiers and polices continue to be comprised of African Guyanese, which has had implications especially for police-community relations. Many Indian Guyanese continue to place little trust in the police to provide public safety, which has led to many Indian businesses hiring private security firms to protect them from criminal activity (Mars, 2009, p. 514). There are numerous vigilante groups that are active in the country-some of which have been accused of "indulging in physical and verbal abuse of citizens" (Mars, 2009, p. 515). While Hoyte's change of leadership both in the Disciplined Forces and the Guyana Police Force was instrumental in the security sector supporting the democratic change of regime in 1992, identity-based tensions between the police and the community continue.

The second source of resilience is the existence of popular counter-narratives to the ethnic divide, in the form of broad-based alternative political parties. In addition to these two parties, two small but significant minority parties have influenced the national of political competition. The Working People's Alliance (WPA), was a class-based party, appealing to the working class of all ethnic groups in the country. Formed originally in 1974 , it remained active after 1992, winning approximately 2 per cent of votes in the 1992, 1997 and 2001 elections (Trefs, 2005, pp. 366-368). The Alliance for Change (AFC) was formed in 2005. It too was multiethnic in appeal, and advocated a reform ticket, which attracted 8.1 per cent of the votes at the 2006 election (Wilson, pp. 87-88), and 10.3 per cent in the 2011 election, securing seven seats (out of sixty-seven) in the parliament (BBC, 2011).

Both parties were influential in the way that they offered counter-narratives to ethnocentrism of the two major parties. By doing so, they challenged both parties to also broaden their appeals. The PPP/C had already attempted this with its "Civic" wing. The PNC's reaction to both the PPP/C's rise to power, and the growing popularity of alternative parties was to also broaden its appeal by trying to win a portion of the Indian vote. This did this by establishing a "Reform" wing, which included the membership of prominent Amerindians (Wilson, 2012, p. 36). PNC/R went on to form a coalition called A Partnership for National Union (AP$\mathrm{NU})$, which the AFC joined prior to the 2015 election. The APNU presented a more diverse membership, and advocated a "celebration of ethnic diversity" to underpin their governance (APNU \& AFC, 2015). At the 2015 election APNU won a majority of seats, precipitating the first change of government since the 1992 election (BBC, 2015). Thus, once the former PNC moved beyond its appeal as an African Guyanese party to incorporate a broader support base, political competition moved beyond its initial bipolar character. The AFC's multiethnic support base-and its counter-narrative to the largely mono-ethnic identity of the two major partieswas instrumental in this shift. The importance of this counter-narrative can be seen in the way that it provided a more inclusive vision of political participation. Previous research on factors that inhibit risk associated with mass atrocities has pointed out that governments and leaders who foster an inclusive ideologytranscending identity-based divisions-can have a strong impact on the mitigation of risk associated with mass atrocities (Mayersen \& McLoughlin, 2011, p. 251; McLoughlin, 2014, p. 157; Straus, 2012, p. 357).

Guyana's period of democratization is not without its challenges. Cheddi Jagan's initial promise to continue reforms after the 1992 election stalled once he won office. Subsequent PPP/C-led governments (under the presidencies of Janet Jagan, Bharrat Jagdeo and Donald Ramotar) became more authoritarian in character (Wilson, 2012, p. 97). However, the security forces' loyalty to the government of the day ensured that a popularly elected government would not be brought down by a coup. This represented a significant change in culture within the armed forces, which itself was a product of the foresight of Desmond Hoyte. In addition, no identity group in Guyana holds an absolute majority in terms of population, unlike the Hutus in Burundi. For Guyana this has opened up the possibility of other counternarratives in the political discourse, led to the election of a multi-ethnic coalition in 2015.

\section{Conclusion}

Since the introduction of free and fair elections in 1992 and 1993 respectively, the fates of Guyana and Burundi could not be more different. Yet neither the atrocities in Burundi, nor the relative stability in Guyana were inevitable from the outset. While Guyana has avoided large-scale violence, tensions remain high, and sporadic political violence still occurs (Hinds, 2010, p. x). Risk is still salient in Guyana-more than two decades of democracy has not entirely eliminated tensions between the two main groups. Burundi's transition took place in a much more volatile environment, yet the violence that escalated in late 1993 was triggered by a relatively obscure leader of one battalion in the military. The military itself was not subject to changes in personnel in the years leading up to 1993, in contrast to the rest of the public sector. Indeed, at independence, Burundi's prospects looked bright, with Uprona effectively representing both Hutus and Tutsis, under the country's royal head of state. Guyana entered independence following inter-ethnic violence, and a deeply divided political landscape. In accounting for why the move away from authoritarian rule in Burundi 
led to widespread atrocities, while similar tensions in Guyana did not escalate violently, this analysis yields three key observations.

First, Burundi's unstable neighbourhood and past atrocities exacerbated risk considerably. A history of atrocities and repression led to highly charged diaspora communities of displaced Hutus in Tanzania and Rwanda, forming militias, seeking to overthrow the Tutsi-led government. The instability and escalating violence in Rwanda further heightened the perceived threat to security that the Tutsi elites experienced. By contrast, Guyana's history of African dominance was not characterized by the same level of violence. Although there was inter-ethnic violence on the eve of independence, subsequent anti-government resistance was mostly voiced through non-violent protests. Harff's claim that prior atrocities are a significant risk factor for future atrocities holds true in these two cases.

Second, political competition in Guyana had another significant dimension during transition. While the return to free and fair elections certainly heightened tensions between those of African and those of Indian descent, non-ethnic alternatives were always visible. During Burnham's tenure, the multi-ethnic WPA provided a counter narrative to the ethnic divide between government and opposition. The AFC later emerged as the main alternative, growing in popularity to win more than 10 per cent of the vote in 2011 , and subsequently forming part of a winning coalition in 2015. Such counter narratives not only provided an alternative for the voting public, but they also pressured the two main parties to broaden their own support bases, thus moderating their rhetoric and images. While counter narratives were also initially present in Burundi in the early years of independence, ${ }^{9}$ the purging of Hutus from the police force and Uprona, and the military coup in 1966 established Tutsi dominance in both the government and the security forces. During the return to multiparty elections in 1993, only Frodebu and Uprona won seats in parliament, although a small number of minor parties also contested (EISA, 2010). The extent to which the demographic breakdown in both countries contributed to different political outcomes warrants further research. Guyana's population of indigenous and other groups comprised a strong support base for the AFC; and the fact that both Indian Guyanese and African Guyanese communities comprised less than half of the population meant that no group could rely on their own ethnic base alone to secure an outright electoral majority. Burundi's population is less diverse, and more bipolar in character. Yet this alone does not

\footnotetext{
9 Two examples stand out. At independence, Burundi was initially a constitutional monarchy, with the monarchy comprising of Ganwa-a princely class that was neither Tutsi nor Hutu. And prior to the 1966 coup, Uprona comprised both Hutus and Tutsi, with the first prime minister being a Hutu.
}

account for the perpetration of atrocities in 1993. Burundi's pre-colonial history was largely stable, with a monarchical structure that transcended this division. It is also clear during Burundi's transition that extremists on both sides played influential roles, further polarizing electoral competition, and lessening the possibility of cooperation rapprochement.

Third, and most significantly is the similarity in the state of the armed forces in both countries at the advent of democratic transition. Both countries had been ruled by minority-led governments with the overt support of the military. In Burundi, the Tutsi-led military had power over the government, and was responsible for crushing dissent in the most extreme ways, even committing genocide in 1972. In Guyana, the military and police comprised predominantly of African Guyanese. During the period of autocratic rule between 1966 and 1992, it effectively functioned "as a tool of African ethnic domination" (Hinds, 2010, p. 41). It was frequently deployed to counter opposition movements, which were largely comprised of Indian Guyanese (Hinds, 2010, p. 11). Yet in Guyana, the shift of power from the PNC to the Indian-dominated PPP in 1992 , did not trigger a military coup and targeted violence as it did in Burundi. Instead, after the defeat of the incumbent PNC in 1992, the armed forces remained loyal to the new government. Indeed the Guyanese armed forces underwent a significant change in culture at the elite level-from being subject principally to Burnham and the PNC, prior to 1985 , to being subject to the country as a whole. This change was brought about by Desmond Hoyte, prior to the 1992 elections. In his efforts to add greater balance to the public sector and government, he made the crucial decision to appoint new (Indian Guyanese) leaders in both the Guyanese Police Force, and the Disciplined Forces. Yet the extent to which this change of leadership affected cooperation with the Disciplined forces demands further scrutiny. More research is needed into precisely how the Disciplined Forces transitioned from a staunch supporter of the authoritarian PNC government, to a more transparent and accountable institution. In particular, more research is needed to attain a better understanding of the extent to which the chief of staff himself changed the culture of the Disciplined Forces.

Similar changes to personnel within government and the public sector were implemented by Buyoya prior to the 1993 elections. Crucially, he did not make any changes to the military. While it would have been impossible to overhaul the composition of the military in such a short time, the case of Guyana provides an illustration of the impact that strategic changes to the armed forces at the elite level can have.

This article's comparative analysis of the early stages of transition in both Guyana and Burundi highlights the ways that pre-existing identity-based tensions can 
escalate in the form of multi-party political competition. The processes of risk mitigation in Guyana were not a panacea to these tensions, but understanding them is insightful in better understanding how such tensions can be managed over time. A combination of elite-driven reform and popular (and inclusive) counter-narratives to the old identity-based divisions provided pressure valves during a volatile period of change. New leadership in the security forces helped to facilitate a change of culture at the top, towards supporting a democratically elected government, rather than simply being loyal to the former PNC government. In Burundi, the continuity of dominance that the military maintained into 1993, ensured that the perpetrators of much of the past atrocities maintained their power. Political reform without a change of culture within the military put them and the Frodebu government at odds with each other, with devastating consequences.

This analysis provides a glimpse of the contributing factors of risk escalation and risk mitigation when similar key variables are at play. Improving our understanding of both why atrocities occur, and how mass atrocity risk is mitigated during democratic transition, yields insights for prevention, both in terms of some of the principal actors responsible for avoiding risk escalation, and in terms of an absence of inhibitive factors during times of heightened tension. The concept of prevention itself has seen a shift over the last few years, from being understood as processes that address the causes of potential deadly violence, to strategies that build resilience and mitigate risk (see Ban Ki-moon, 2013). This shift in approach demands that we better understand not only why atrocities occur, but also how and why they are avoided.

\section{Acknowledgments}

I would like to thank Michael S. Lund and the anonymous reviewers for comments on earlier drafts of this paper.

\section{Conflict of Interests}

The author declares no conflict of interests.

\section{References}

Abrams, Jason S. (1995). Burundi: Anatomy of an Ethnic Conflict. Survival, 37(1), 144-164.

African Elections Database. (2015). Elections in Burundi. Retrieved from http://africanelections.tripod. com/bi.html\#1992_Constitutional_Referendum

A Partnership for National Unity (APNU) and the Alliance for Change (AFC). (2015). Our Vision for Unity, Stability and Development. Retrieved from http:// gtmosquito.com/wp-content/uploads/2015/04/ manifesto.pdf
BBC News. (2011, December 2). Guyana Governing Party's Donald Ramotar wins Presidency. BBC News. Retrieved from http://www.bbc.com/news/worldlatin-america-15980149

BBC News. (2015, May 12). Ex-general David Granger wins Guyana election. $B B C$ News. Retrieved from http://www.bbc.com/news/world-latin-america32747514

Bowen, M., Freeman, G., \& Miller, K. (1973). Passing By: The United States and Genocide in Burundi. Washington DC: Carnegie Endowment for International Peace.

Carnegie Commission on Preventing Deadly Conflict. (1997). Preventing deadly conflict: Final report. Washington, DC: Carnegie Commission on Preventing Deadly Conflict.

Chrétien, J-P. (2003). The great lakes of Africa. New York: Zone Books.

Collier, P., \& Rohner, D. (2008). Democracy, development and conflict. Journal of the European Economic Association 6(2-3), 531-540.

Collier, P. (2009). Wars, guns and votes: Democracy in dangerous places. New York: Harper Perennial.

Department of Foreign Affairs and Trade (DFAT). (2013). Governance. Retrieved from http://aid.dfat. gov.au/aidissues/governance/Pages/home.aspx

Department for International Development (DFID). (2013). Helping developing countries to be betterrun and more accountable. Retrieved from https://www.gov.uk/government/policies/helpingdeveloping-countries-to-be-better-run-and-moreaccountable

Electoral Institute for Sustained Democracy in Africa (EISA). (2010). Burundi 1993 National Assembly election results. Retrieved from http://www.content. eisa.org.za/old-page/burundi-1993-national-assembl y-election-results

Goldstone, J., \& Ulfelder, J. (2004). How to construct stable democracies. The Washington Quarterly, 28(1), 9-20.

Griffith, I. (1991). The military and the politics of change in Guyana. Journal of Interamerican Studies and World Affairs, 33(2), 141-173.

Griffith, I. (1997a). Democracy and human rights in Guyana. In I. Griffith \& B. Sedoc-Dalhberg (Eds.), Democracy and human rights in the Caribbean. Boulder CO: Westview Press.

Griffith, I. (1997b). Political change, democracy and human rights in Guyana. Third World Quarterly, 18(2), 267-285.

Guyana Times. (2014, December 30). Danger of army in politics. Guyana Times. Retrieved from http:// www.guyanatimesgy.com/2014/12/30/danger-ofarmy-in-politics

Harff, B. (2003). No lessons learnt from the Holocaust? Assessing the risks of genocide and mass murder since 1955. The American Political Science Review, 
97(1), 57-73.

Hinds, D. (2010). Ethno-politics and power sharing in Guyana: History and discourse. Washington D.C.: New Academia Publishing.

Human Rights Watch. (2009, August 13). Burundi: Seek justice for war crimes victims. Human Rights Watch. Retrieved from http://www.hrw.org/news/2009/ 08/13/burundi-seek-justice-war-crimes-victims

Human Security Report Project. (2011). Human security report 2009/2010: The causes of peace and the shrinking costs of war. New York: Oxford University Press.

Jagan, C. (1997). The west on trial: My fight for Guyana's freedom. St John's Antigua: Hansib.

Kalyvas, S. (2006). The logic of violence in civil war. Cambridge: Cambridge University Press.

Ki-moon, B. (2013). The responsibility to protect: State responsibility and prevention (A/67/929-S/2013/ 399). New York: United Nations.

Krain, M. (2000). Democracy, internal war, and statesponsored mass murder. Human Rights Review, 1(3), 1-24.

Kuper, L. (1981). Genocide: Its political use in the twentieth century. New Haven: Yale University Press.

Lemarchand, R. (1994). Managing transition anarchies: Rwanda, Burundi and South Africa in comparative perspective. The Journal of Modern African Studies, 32(4), 581-604.

Lemarchand, R. (1996). Burundi: Ethnic conflict and genocide. Cambridge: Cambridge University Press.

Mann, M. (2005). The dark side of democracy: Explaining ethnic cleansing. Cambridge: Cambridge University Press.

Mars, J. (2009). Ethnic diversity and police-community relations in Guyana. Commonwealth and Comparative Politics, 47(4), 506-516.

Mars, P. (2001). Ethnic politics, mediation and conflict resolution: The Guyana experience. Journal of Peace Research, 38(3), 353-372.

Mayersen, D., \& McLoughlin, S. (2011). Risk and resilience to mass atrocities in Africa: A comparison of Rwanda and Botswana. Journal of Genocide Research, 13(3), 247-269.

McLoughlin, S. (2014). The structural prevention of mass atrocities: Understanding risk and resilience. Oxon: Routledge.

McLoughlin, S. (2014a). Rethinking the structural prevention of mass atrocities. Global Responsibility to Protect, 6(4), 407-429.

McLoughlin, S., \& Mayersen, D. (2013). Reconsidering root causes: A new framework for the structural prevention of mass atrocities. In B. Ingelaere, S. Parmentier, J. Haers, \& B. Segaert (Eds.), Genocide, risk and resilience: An interdisciplinary approach. Basingstoke: Palgrave Macmillan.

Mthembu-Salter, G., Berger, E., \& Kikoler, N. (2011). Prioritizing protection from mass atrocities: lessons from Burundi (Occasional Paper Series). New York: Global Centre for the Responsibility to Protect.

Prunier, G. (1994). Burundi: A manageable crisis? Writenet. Retrieved from http://repositories.lib. utexas.edu/bitstream/handle/2152/5200/2505.pdf ?sequence $=1$

Prunier, G. (2009). Africa's world war: Congo, the Rwandan genocide, and the making of a continental catastrophe. Oxford: Oxford University Press.

Reyntjens, F. (1993). The proof of the pudding is in the eating: The June 1993 elections in Burundi. The Journal of Modern African Studies, 31(4), 562-583.

Reyntjens, F. (2005). Burundi: Prospects for peace (MRG International Report). London: Minority Rights Group International.

Rummel, R. J. (1994). Death by government: Genocide and mass murder since 1900. Somerset, NJ: Transaction.

Rummel, R. J. (1997). Power kills: Democracy as a method of nonviolence. Somerset, NJ: Transaction.

Semelin, J. (2007). Purify and destroy: The political uses of massacre and genocide. London: C. Hurst \& Co.

Singh, C. (2008). Re-democratization in Suriname and Guyana: Critical comparisons. European Review of Latin American and Caribbean Studies, 84, 71-85.

Snyder, J. (2000). From voting to violence: Democratization and nationalist conflict. New York: W. W. Norton \& Company.

Stewart, F. (2008). Horizontal inequalities and conflict: An introduction and some hypotheses. In F. Stewart (Ed.), Horizontal inequalities and conflict: Understanding group violence in multi-ethnic societies. New York: Palgrave Macmillan.

Straus, S. (2012). Retreating from the brink: Theorizing mass violence and the dynamics of restraint. Perspectives on Politics, 10(2), 343-362.

Trefs, M. (2005). Guyana. In D. Nohlen (Ed.), Elections in the Americas: A data handbook, vol. 1. Oxford: Oxford University Press.

USAID. (2013). Democracy, human rights and governance. USAID. Retrieved from http://www.usaid. gov/what-we-do/democracy-human-rights-andgovernance

Uvin, P. (1999). Ethnicity and power in Burundi and Rwanda: Different paths to mass violence. Comparative Politics, 31(3), 253-271.

Uvin, P. (2009). Life after violence: A people's story of Burundi. London: Zed Books.

Valentino, B. A. (2004). Final solutions: Mass killing and genocide in the $20^{\text {th }}$ century. Ithaca: Cornell University Press.

Weinstein, W. (1972). Conflict and confrontation in Central Africa: The revolt in Burundi, 1972. Africa Today, 19(4).

Wilson, S. (2012). Politics of identity in small plural societies: Guyana, the Fiji Islands, and Trinidad and Tobago. New York: Palgrave. 
Wolpe, H. (2011). Making peace after genocide: Anatomy of the Burundi process. Washington: United States Institute of Peace. Retrieved from
http://www.usip.org/sites/default/files/PW_Burun di.pdf

\section{About the Author}

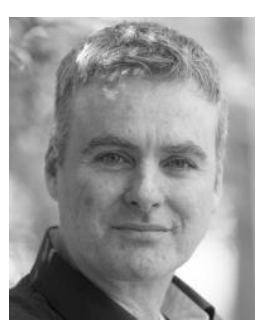

\section{Dr. Stephen McLoughlin}

Stephen McLoughlin is a Research Fellow at the Griffith Asia Institute and Centre for Governance and Public Policy, at Griffith University. His research interests include mass atrocities early warning, structural prevention of mass atrocities, ethnic conflict in post-communist states, and the responsibility to protect. His current research is focused on understanding local and national sources of resilience, and how these play a protective role in states at risk of future atrocities. 